\title{
Telbivudine can safely reduce mother-to- child transmission in chronic hepatitis B women after 12 weeks of gestation
}

\author{
Li-fen Han', Jian-ming Zheng ${ }^{2}$, Li-qing Zheng ${ }^{1}$, Hai-bing Gao' ${ }^{1}$ Li-xia Chen ${ }^{1}$, Qing-ling X ${ }^{1}$, Yi-hong Chai ${ }^{1}$, \\ Xin Zhang ${ }^{3}$, Chen Pan ${ }^{1}$ and Lv-feng Yao ${ }^{1 *}$
}

\begin{abstract}
Background: To evaluate the efficacy and safety of telbivudine in chronic hepatitis B women during the second and third trimesters of pregnancy.

Methods: The week 12-34 of pregnant women were screened in this prospective non-intervention study, with HBV DNA $>10^{6} \mathrm{IU} / \mathrm{mL}$ and alanine aminotransferase $>50 \mathrm{IU} / \mathrm{L}$. The patients were received telbivudine treatment as a treatment group or without antiviral treatment as a control group. All infants were received recombinant hepatitis $\mathrm{B}$ vaccine $10 \mu \mathrm{g}$ within $12 \mathrm{~h}$ of birth, at week 4 and week 24 , immunoglobulin $\mathrm{G}$ within $12 \mathrm{~h}$ of birth and were detected HBV markers at the range from 7 to 12 months after delivery.

Results: A total of 241 patients were finally enrolled, 139 patients in telbivudine group and 102 patients in control group. HBsAg negative rate of infants was 99.3\% (135/136) in telbivudine group and was 91.9\% (91/99) in control group after 7 months $(P=0.005)$, respectively. The incidence of undetectable HBV DNA levels $(47.5 \%)$ was significantly lower in telbivudine-treated mothers than that in the controls $(0 \%)$, and $75.5 \%$ patients alanine aminotransferase returned to normal in telbivudine group, and $51 \%$ in control group at delivery $(P<0.001)$, respectively.

Conclusions: Telbivudine can safely reduce mother-to-child transmission in chronic hepatitis B women after 12 weeks of gestation.
\end{abstract}

Keywords: Telbivudine, Mother-to-child transmission, Chronic hepatitis B

\section{Background}

Although the weighted prevalence of hepatitis B surface antigen (HBsAg) for Chinese population aged 1-59 years were $7.2 \%$, immunization program should be further strengthened to reach those remaining at highest risk [1]. Perinatal or mother-to-child transmission (MTCT) is the most common form of transmission of hepatitis B virus (HBV) in many high-prevalence areas, particularly in Asian countries. The regions of the world where HBV genotype $\mathrm{C}$ is found as MTCT is associated with high maternal viral load (HBV DNA $>10^{6} \mathrm{IU} / \mathrm{mL}$ ), and may occur in up to $90 \%$ of mothers who are HBsAg positive and hepatitis $\mathrm{B}$ e antigen ( $\mathrm{HBeAg}$ ) positive in the

\footnotetext{
* Correspondence: yaolf05@163.com

${ }^{1}$ Department of Liver Diseases, Mengchao Hepatobiliary Hospital of Fujian Medical University, Fuzhou 350025, China

Full list of author information is available at the end of the article
}

absence of prophylaxis [2-9]. Application of Hepatitis B vaccine combined with Hepatitis B immune globulin (HBIG) considerably reduced perinatal transmission [10]. However, in a previous study from China, the rate of immunoprophylaxis failure by predelivery HBV DNA levels, was $0 \%$ for levels $<10^{6}$ copies $/ \mathrm{mL}, 3.2 \%$ for levels of 6-6.99 $\log _{10}$ copies $/ \mathrm{mL}, 6.7 \%$ for levels between 7 and $7.99 \log _{10}$ copies $/ \mathrm{mL}$, and $7.6 \%$ for levels $>8 \log _{10}$ copies $/ \mathrm{mL}$, respectively [9]. No perinatal transmission has also been reported in infants born to mothers with viral loads $<6 \log _{10}$ copies $/ \mathrm{mL}$ in other studies $[6,11]$. The HBV DNA threshold to consider antiviral therapy to prevent perinatal transmission is $>2 \times 10^{5} \mathrm{IU} / \mathrm{mL}$ [9]. The use of these agents in $\mathrm{HBeAg}$ positive women whose HBV DNA are $>10^{6}$ copies $/ \mathrm{mL}$ in the third trimester to prevent MTCT is recommended [12]. Thus, antiviral therapy was started at 28-32 weeks of gestation

(c) The Author(s). 2019 Open Access This article is distributed under the terms of the Creative Commons Attribution 4.0 International License (http://creativecommons.org/licenses/by/4.0/), which permits unrestricted use, distribution, and reproduction in any medium, provided you give appropriate credit to the original author(s) and the source, provide a link to the Creative Commons license, and indicate if changes were made. The Creative Commons Public Domain Dedication waiver (http://creativecommons.org/publicdomain/zero/1.0/) applies to the data made available in this article, unless otherwise stated. 
in most of the studies [13]. It's still have failed immunoprophylaxis in some high viral load mothers, so antiviral therapy start at a earlier time may be considered such as at the second trimesters of pregnancy [14]. Since tenofovir is not approved for the treatment of chronic hepatitis B (CHB) before 2014 in China and very expensive, the use of telbivudine would appear to be a favorable treatment option for $\mathrm{CHB}$ mothers [15]. Moreover, some previous studies found that patients in the telbivudine group had significantly lower $\mathrm{HBV}$ DNA and $\mathrm{HBeAg}$ levels and higher HBV DNA negative conversion rates compared to those in the lamivudine group before delivery $[16,17]$. Thus, we performed this study to evaluate the efficacy and safety of using telbivudine treatment started at 12-34 weeks of gestation in HBeAg positive or negative $\mathrm{CHB}$ mothers (rare of the studies including HBeAg negative mothers) on MTCT prevention, HBV DNA suppression, and maternal and fetal safety including major birth defect rates.

\section{Methods \\ Patients}

A total of 241 pregnant women with chronic hepatitis B treated from January 2012 to March 2015 at Mengchao Hepatobiliary Hospital of Fujian Medical University, were enrolled finally. Inclusion criteria were: (1) age between 18 and 45 years, (2) gestational age between 12 and 34 weeks, (3) a history of serum HBsAg positivity for more than 6 months, (4) serum HBV DNA > $10^{6} \mathrm{IU} / \mathrm{mL}$, (5) serum alanine aminotransferase (ALT) above upper limit of normal (ULN) $(50 \mathrm{IU} / \mathrm{mL})$ and/or serum aspartate transaminase (AST) above ULN (40 IU/mL), (6) serum total bilirubin (TBIL) below $125 \mu \mathrm{mol} / \mathrm{L}$. Exclusion criteria included: (1) liver failure or cirrhosis, (2) coinfection with hepatitis A, C, D or E, syphilis or human immunodeficiency virus, (3) with severe respiratory, circulatory, urinary or nervous system diseases, (4) a history of antiviral therapy, (5) clinical signs of threatened miscarriage in early time of pregnancy, (6) concurrent treatment with immune modulators, cytotoxic drugs, or steroids. Withdrawal criteria were: (1) poor compliance and lack of regular follow-up, (2) administration of other drugs, e.g. immunomodulators, cytotoxic drugs or steroids during the following time, (3) switch to other treatment (for example, patients in control group were received telbivudine or other antiviral drugs in this study). This prospective observational study was approved by the Ethics Committee of Mengchao Hepatobiliary Hospital of Fujian Medical University (award number 2011-001-01), and all the patients signed informed consent. All procedures were in accordance with the Helsinki Declaration of 1975. The written consent was obtained from every mother, and all subjects consented before screening for the study. The patients were assigned to the telbivudine group or without antiviral treatment groups according to their own preferences.

\section{Treatment}

In our study, 139 patients were received telbivudine as telbivudine group and 102 patients without antiviral treatment as control group, according to their own preferences at the baseline. The telbivudine group were administered telbivudine (Sebivo, $600 \mathrm{mg} / \mathrm{d}$, Beijing Novartis Pharma Ltd.) from 12 to 34 weeks of gestation. The patients in control group were not received any antiviral drug, but received agents for improving liver function. All of the patients in two groups with abnormal liver function were received glycyrrhizin (Minophagen Pharmaceutical Co., Ltd., Japan), Polyene Phosphatidylcholine (Essentiale, Sanofi Beijing Pharma Ltd.), ademetionine (Simeitai, Abbott Laboratories Ltd.) or other agents for improving liver function. The patients in telbivudine group continued to use telbivudine treatment after delivery.

All newborns were vaccinated with genetically engineered hepatitis $\mathrm{B}$ vaccine $10 \mu \mathrm{g}$ in the deltoid muscle within $12 \mathrm{~h}$ of birth, at week 4 and 24 and HBIG 100$200 \mathrm{IU}$ in the gluteus maximums within $12 \mathrm{~h}$ of birth. Due to the lack of safety data for breastfeeding with antiviral treatment, breastfeeding was not encouraged in our study and all newborns were bottle-fed in telbivudine group. Breast feeding could have been allowed for control group as this is not a blinded study.

\section{Outcomes assessments}

The enrolled women received routine physical examination during pregnancy. The liver function, HBV markers, HBV DNA, Creatine kinase (CK), routine blood test and renal function were assessed regularly. Renal function and CK were monitored every 2-4 weeks in telbivudine group. Recently, new evidences recommended that infants who were seropositive for $\mathrm{HBsAg}$ and HBV DNA at 7 months could be identified as having acquired HBV infection $[15,18,19]$. Thus, serum HBV markers of infants was measured once at the time range from 7 to 12 months after delivery due to not all infants were able to be assessed at 7 months after delivery in our study. The liver function, renal function and CK were assessed on an Beckman Coulter Biochemistry Analyzer with corollary reagents. HBV serum markers were detected by the Abbott chemiluminescence assay based on ARCHITECT i2000SR. Serum HBV DNA levels were detected by fluorescence quantitative PCR (Shanghai Fosun Pharmaceutical Co., Ltd.) based on ABI7500, with a detection range from $500 \mathrm{IU} / \mathrm{mL}$ to $10^{9}$ $\mathrm{IU} / \mathrm{mL}$. HBeAg conversion was defined that $\mathrm{HBeAg}$ was loss and Hepatitis B e antibody (HBeAb) was positive after antiviral treatment. 


\section{Statistical analysis}

Statistical analysis were performed using the SPSS19.0 (SPSS, Inc., Chicago, IL) software. Continuous variables were expressed as mean \pm standard deviation (SD) unless otherwise specified, and t tests or non-parametric MannWhitney U-test were used for comparing differences between two groups if necessary. For categorical variables, the chi-square test or Fisher exact test was used for group comparisons. Significance level was set at $P<0.05$.

\section{Results}

\section{Baseline characteristics}

A total of 288 at $12-34$ weeks of gestation women with chronic hepatitis B were screened, 23 patients did not meet the eligibility criteria and were excluded. In the remaining 265 individuals, there were 143 patients in telbivudine group and 122 patients in control group. However, 4 patients and 20 patients withdrew from the study in each group, respectively. Therefore, there were 139 patients in telbivudine group and 102 patients in control group in our study cohort finally (Fig. 1). In telbivudine group, three patients started antiviral treatment at 12 weeks, 1 patient started at 13 weeks, 5 patients started at 14 weeks, 5 patients started at 15 weeks, 4 patients started at 16 weeks, 2 patients started at 17 weeks, 8 patients started at 18 weeks, 5 patients started at 19 weeks, 4 patients started at 20 weeks, 9 patients started at 21 weeks, 5 patients started at 22 weeks, 7 patients started at 23 weeks, 2 patients started at 24 weeks, 6 patients started at 25 weeks, 9 patients started at 26 weeks, 4 patients started at 27 weeks, 18 patients started at 28 weeks, 8 patients started at 29 weeks, 8 patients started at 30 weeks, 6 patients started at 31 weeks, 8 patients started at 32 weeks, 5 patients started at 33 weeks, 7 patients started at 34 weeks, respectively. In telbivudine group, $57.6 \%(80 / 139)$ patients started antiviral therapy at week 12-27 of gestation. Baseline characteristics of mothers was summarized in the Table 1.

\section{Efficacy of telbivudine treatment}

At delivery, $75.5 \%(105 / 139)$ of patients ALT returned to normal in telbivudine group, compared to $51 \%(52 / 102)$ of patients in the control group $\left(X^{2}=15.627, P<0.001\right)$. AST in telbivudine group was lower than that in control group $\left(X^{2}=19.643, P<0.001\right)$, but TBIL was no different between two group (Table 2 and Fig. 2). In telbivudine group, the patients were received telbivudine for an average of $13 \pm 6$ weeks, and HBV DNA levels was declined to $2.82 \log _{10} \mathrm{IU} / \mathrm{mL}$ at delivery, compared to the baseline ( $\mathrm{U}=13, P<0.001)$. HBV DNA level was declined after telbivudine treatment, but it didn't decline in control group (Fig. 3). There was no statistically

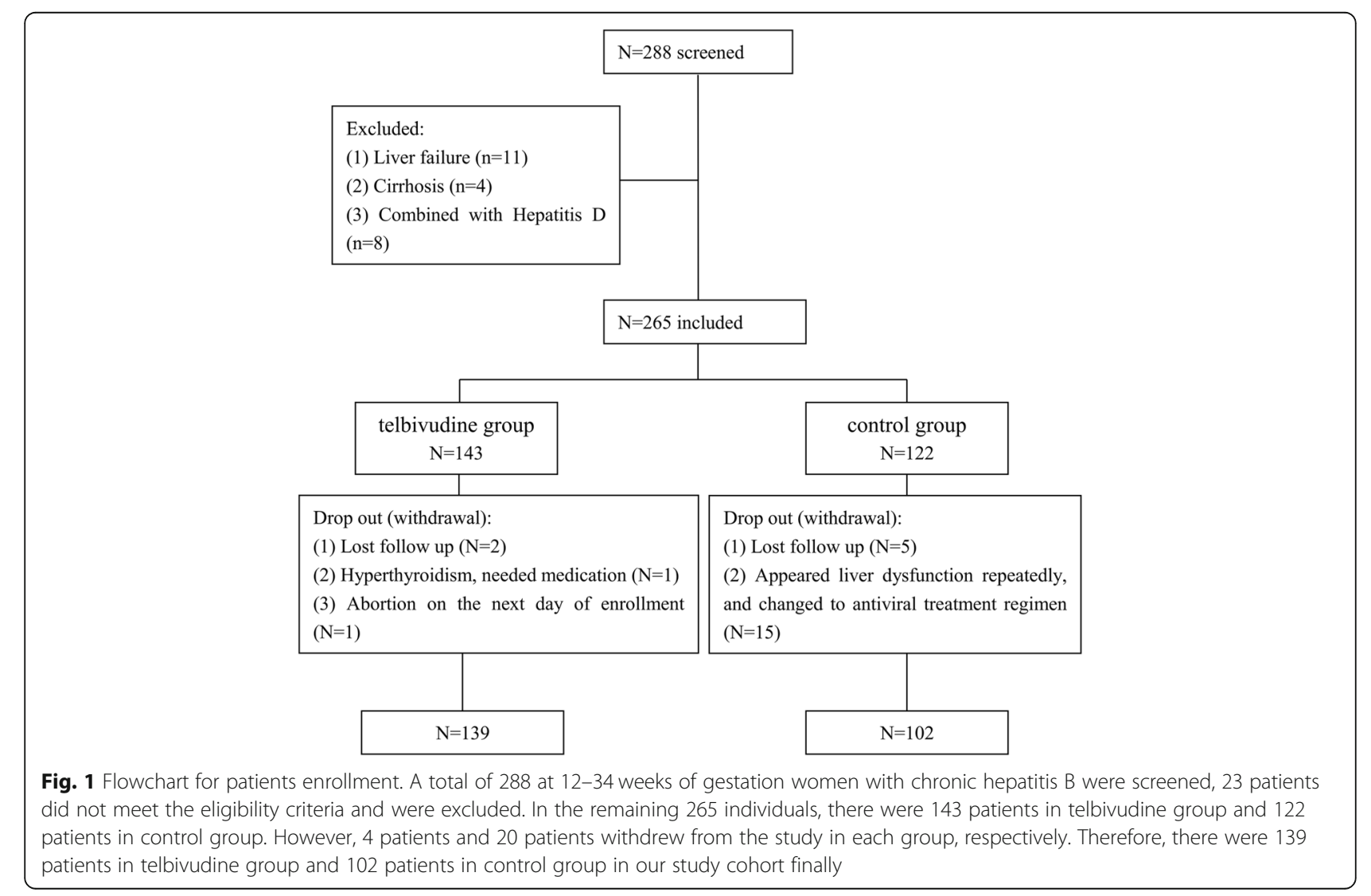


Table 1 Baseline characteristics of mothers

\begin{tabular}{llll}
\hline Characteristics of mothers & $\begin{array}{l}\text { Telbivudine group } \\
(N=139)\end{array}$ & $\begin{array}{l}\text { Control group } \\
(N=102)\end{array}$ \\
\hline Age, years, median (range) & $26(20-43)$ & $26(18-42)$ & $1(1-4)$ \\
Prior pregnancy, median (range) & $1(1-4)$ & $7.72(6.03 \sim 9.00)$ & 0.061 \\
HBV DNA levels, log 10 IU/mL, median (range) & $7.73(6.04 \sim 9.30)$ & $45(44.1 \%)$ & 0.224 \\
HBV DNA levels $>10^{8} \mathrm{IU} / \mathrm{mL}, \mathrm{n}(\%)$ & $60(43.2 \%)$ & $36(35.3 \%)$ & 0.858 \\
HBV DNA levels $10^{7}-10^{8} \mathrm{IU} / \mathrm{mL}, \mathrm{n}(\%)$ & $62(44.6 \%)$ & $164(53-1025)$ & 0.883 \\
ALT level, U/L, median (range) & $117(56-1166)$ & $101(35-539)$ & 0.184 \\
AST level, U/L, median (range) & $112(32-1061)$ & $101(99.0 \%)$ & 0.867 \\
Elevated AST levels, $\mathrm{n}(\%)$ & $136(97.8 \%)$ & $11(3-96)$ & 0.301 \\
TBIL, $\mu$ mol/L, median (range) & $11(4-125)$ & $91(89.2 \%)$ & 0.640 \\
HBeAg positive, $\mathrm{n}(\%)$ & $126(90.6 \%)$ & 0.714 \\
\hline
\end{tabular}

significant difference between HBV DNA levels at baseline and that at delivery in control group (Fig. 2). At delivery, HBV DNA levels in telbivudine group was lower than that in control group $(U=28, P<0.001)$. Furthermore, HBV DNA levels of 47.5\% (66/139) patients were undetectable at delivery in telbivudine group, but none of the patients HBV DNA levels was undetectable in the control group $(P<0.001)$. All patients were follow-up for 6 months after delivery. The patients in telbivudine group continued to use telbivudine treatment after delivery, but five patients stopped telbivudine treatment after delivery. HBV DNA levels of one patient who stopped telbivudine, increased up to $8 \log _{10} \mathrm{IU} / \mathrm{mL} 2$ months later, then ALT was $433 \mathrm{U} / \mathrm{L}$ and AST was $160 \mathrm{U} / \mathrm{L} 3$ months later. This patient's liver function returned to normal again after 2 months antiviral treatment with Pegasys and entecavir. The liver function of other patients remained normal, who stopped antiviral treatment, but HBV DNA levels were ranged from $5.00 \log _{10}$ $\mathrm{IU} / \mathrm{mL}$ to $8.64 \log _{10} \mathrm{IU} / \mathrm{mL}$. None of them had virological breakthrough, who continued to use telbivudine therapy. Among the $126 \mathrm{HBeAg}$ positive mothers in telbivudine group, $14.3 \%(18 / 126)$ patients had $\mathrm{HBeAg}$ seroconversion at delivery. However, none of patients (91 HBeAg positive patients) had HBeAg seroconversion in control group $(P<0.001)$.

Finally, 137 infants were born in telbivudine group, 99 infants were in control group $(P=1.0)$, respectively. All newborns were vaccinated with genetically engineered hepatitis $B$ vaccine $10 \mu \mathrm{g}$ in the deltoid muscle within $12 \mathrm{~h}$ of birth, at week 4 and 24 and HBIG 100-200 IU in the gluteus maximums within $12 \mathrm{~h}$ of birth. HBsAg was screened in 235 infants at the age ranged from 7 to 12 months, due to one infant died of ruptured abdominal aortic aneurysm at 8 days after delivery in telbivudine group. HBsAg negative rate of infants was $99.3 \%$ (135/136) in telbivudine group, and was $91.9 \%(91 / 99)$ in control group $(P=0.005)$, respectively. The mother of HBsAg positive infant in telbivudine group, whose $\mathrm{HBeAg}$ was positive, had received telbivudine treatment since week 34 of gestation and her serum HBV

Table 2 Efficacy of telbivudine treatment

\begin{tabular}{|c|c|c|c|}
\hline & $\begin{array}{l}\text { Telbivudine } \\
(N=139)\end{array}$ & $\begin{array}{l}\text { Control } \\
(N=102)\end{array}$ & $P$ value \\
\hline \multicolumn{4}{|l|}{ HBV DNA, $\log _{10} \mathrm{IU} / \mathrm{mL}$, median (range) } \\
\hline Week 2 & $5.51(3.04-8.06)$ & $7.74(6.03-9.00)$ & $<0.001$ \\
\hline Week 4 & $4.12(2.70-7.43)$ & $7.70(6.03-9.00)$ & $<0.001$ \\
\hline Week 8 & $3.20(2.70-6.76)$ & $7.74(6.03-9.00)$ & $<0.001$ \\
\hline At delivery & $2.82(2.70-6.45)$ & $7.72(5.32-9.00)$ & $<0.001$ \\
\hline ALT levels at delivery, $U / L$, median (range) & $28(11-238)$ & $47(8-217)$ & $<0.001$ \\
\hline Normalization rate of ALT, n (\%) & $105(75.5 \%)$ & $52(51 \%)$ & $<0.001$ \\
\hline AST levels at delivery, $U / L$, median (range) & $27(11-141)$ & $39(17-144)$ & $<0.001$ \\
\hline Normalization rate of AST, n (\%) & $112(80.6 \%)$ & $55(53.9 \%)$ & $<0.001$ \\
\hline TBIL levels at delivery, U/L, median (range) & $1.1(9.8-36.0)$ & $9.5(3.8-48.6)$ & 0.459 \\
\hline Normalization rate of TBIL, n (\%) & $137(98.6 \%)$ & $100(98.0 \%)$ & 1.000 \\
\hline HBeAg positive at delivery, n (\%) & $108(77.7 \%)$ & $91(89.2 \%)$ & 0.025 \\
\hline
\end{tabular}



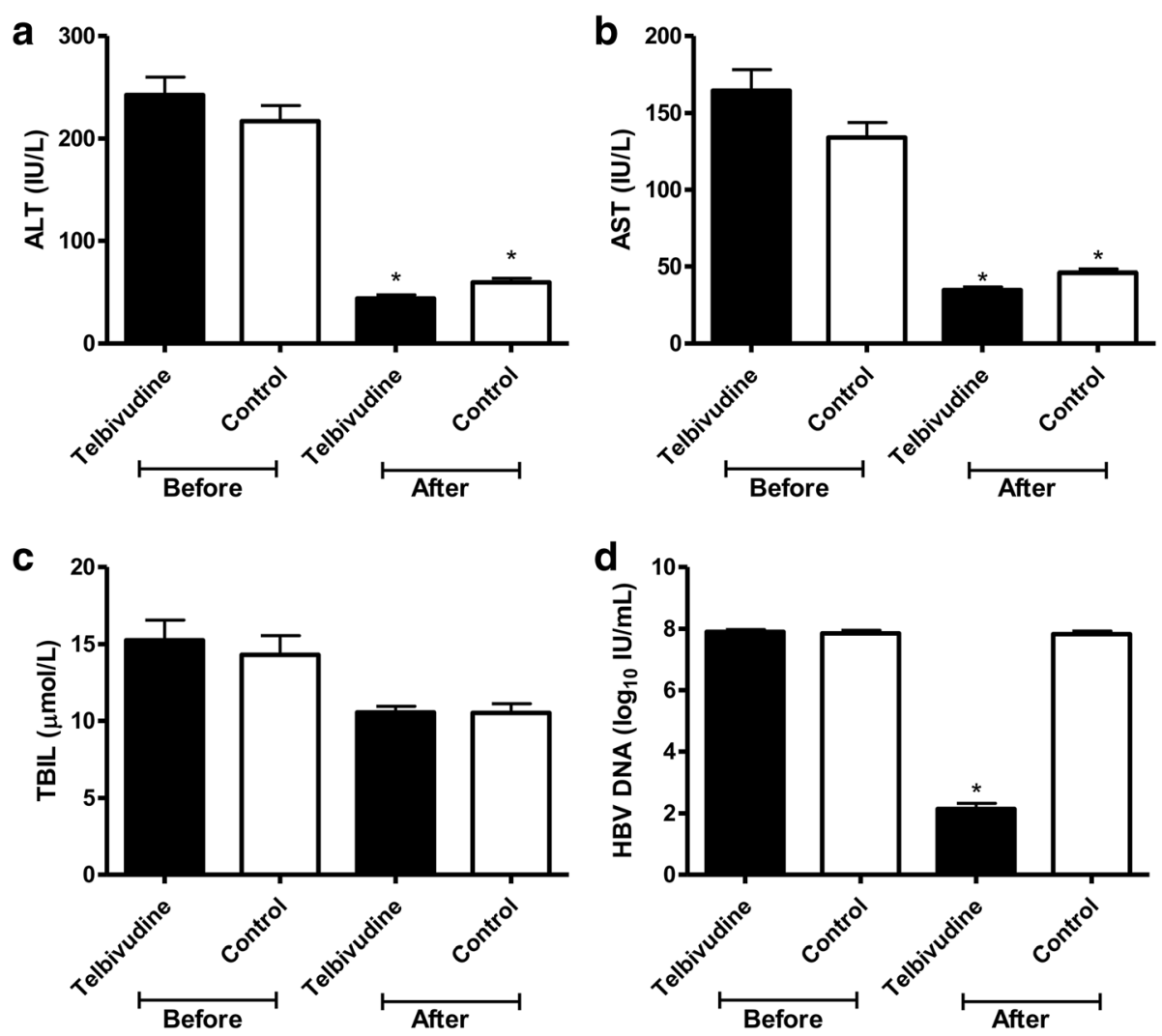

Fig. 2 ALT, AST, TBIL and HBV DNA levels at baseline and at delivery. Panel a was ALT, panel b was AST, panel $\mathbf{c}$ was TBIL, and panel $\mathbf{d}$ was HBV DNA.* means $P<0.05$, compared with that before the treatment in the same drug group

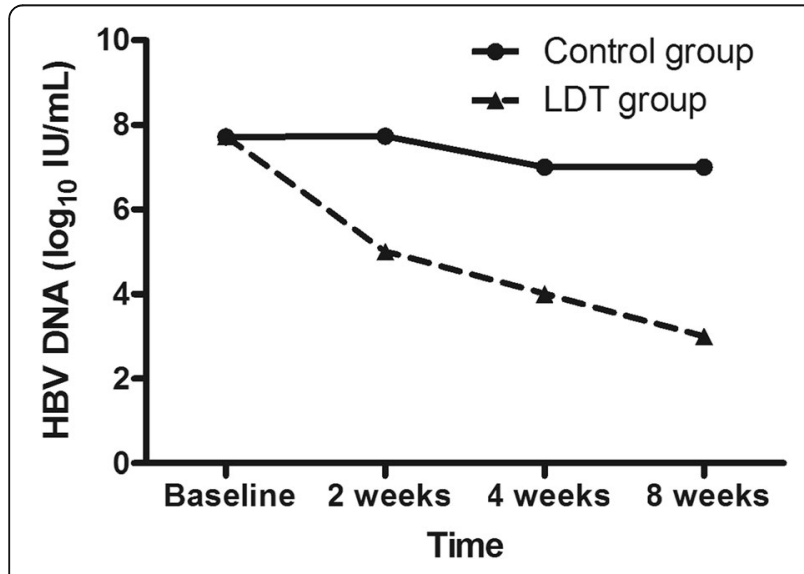

Fig. 3 HBV DNA levels in different groups. There was no statistically significant difference between HBV DNA levels in telbivudine group and that in control group at baseline. HBV DNA levels at 2 weeks, 4 weeks and 8 weeks in telbivudine group was lower than that at the same time in control group $(P<0.0001)$
DNA levels was $6.15 \log _{10} \mathrm{IU} / \mathrm{mL}$ at delivery. In control group, the HBV DNA levels of patients who had HBsAg positive infant was $8.33 \pm 0.88 \log _{10} \mathrm{IU} / \mathrm{mL}$, compare with that of patients had HBsAg negative infant was 7.69 (median, ranged from 5.32-9.00) $\log _{10} \mathrm{IU} / \mathrm{mL}(\mathrm{U}=259$, $P=0.141$ ). In control group, $11 \mathrm{HBeAg}$ negative mothers had 11 infants and only one infant's HBsAg was positive. $\mathrm{HBsAg}$ negative rate of infants in HBeAg negative mothers in control group was no significant difference compared with $\mathrm{HBeAg}$ positive mothers in control group $(P=1.000)$. $\mathrm{HBsAg}$ negative rate of infants in $\mathrm{HBeAg}$ negative mothers in telbivudine group was also no significant difference compared with $\mathrm{HBeAg}$ positive mothers in telbivudine $\operatorname{group}(P=0.458)$. The liver function of HBsAg positive infants was normal, so they were planned to follow up every 6 month.

\section{Safety of telbivudine treatment}

Creatine kinase of 7 patients slightly increased in the telbivudine group after antiviral treatment, and the maximum value was $367 \mathrm{U} / \mathrm{L}$. None of them presented obvious symptoms. CK did not increase in any patient of control group, and was statistically significant difference compared with that of telbivudine group $(P=0.022)$. 
The rate of adverse events was $4.3 \%$ (6/139) in telbivudine group, and was $5.9 \%(6 / 102)$ in control group $\left(x^{2}=0.305, P=0.581\right)$, respectively (Table 3$)$.

The median of gestational age was 38 weeks in telbivudine group, and 38 weeks in control group $(U=6217$, $P=0.085)$, respectively. The rate of cesarean section was $35 \%$ in telbivudine group, and $36 \%$ in control group $(P=0.892)$, respectively. The rates of cesarean section were high in this study, but consistent with the rate of cesarean section observed in China [20]. In telbivudine group, one infant had abdominal aortic aneurysm. In control group, one infant had cleft lip. However, there no significant difference on birth defect between two groups $(P=1.000)$ (Table 3$)$.

\section{Discussion}

According to national guidelines 2010 version, application of Hepatitis B vaccine combined with HBIG is as the standard of care for prevent MTCT of HBV in China. By the end of 2015, the use of lamivudine, telbivudine or tenofovir in $\mathrm{HBeAg}$ positive women whose HBV DNA are $>10^{6}$ copies $/ \mathrm{mL}$ at $28-32$ weeks of gestation is added as a new method in Chinese guide 2015 version to prevent MTCT [21, 22]. In our study, antiviral therapy was started at week 12-34 of pregnancy, some of them started antiviral therapy earlier than previous studies, which antiviral therapy was started at week 2832 of pregnancy according to the American Association for the Study of Liver Disease (AASLD) guideline [13]. In the telbivudine group, only one infant's HBsAg was positive after 7 months, whose mother started antiviral therapy at 34 weeks of gestation. It maybe too later, so her HBV DNA levels was still above $6 \log _{10} \mathrm{IU} / \mathrm{mL}$ at delivery. If the patient who started antiviral therapy at 34 weeks of pregnancy was not included in our study, the rate of immunoprophylaxis failure was zero. That is very encouraging and impressive. About 57.6\% patients started antiviral therapy at week $12-27$ of gestation, but adverse events reported in telbivudine group was similar to control group.

In our study, we enrolled the patients who started antiviral treatment at ALT above > one fold the upper limit of normal, which is lower than AASLD or Asian Pacific Association for the Study of the Liver (APASL) guideline, but the same as the European Association for

Table 3 Adverse events reported in this study

\begin{tabular}{llll}
\hline & Telbivudine & Control & $P$ value \\
\hline CK Elevation of mother, $\mathrm{n}(\%)$ & $7(5 \%)$ & $0(0 \%)$ & 0.022 \\
Malformation induced labor, $\mathrm{n}$ & 1 & 1 & 1.000 \\
Abortion, $\mathrm{n}$ & 1 & 2 & 0.575 \\
Premature labor, $\mathrm{n}$ & 3 & 2 & 1.000 \\
Congenital diseases, $\mathrm{n}$ & 1 & 1 & 1.000 \\
\hline
\end{tabular}

the Study of the Liver (EASL) guideline [13, 23, 24]. Thus, more people may achieve benefit from our study.

Treatment was usually administered in the second and third trimesters of gestation, because the most sensitive period of fetal development generally occurs in the first trimester, especially at the first 8 weeks of pregnancy [25]. Telbivudine is an L-reverse transcriptase inhibitor, and has shown no effects on human nucleotides or DNA synthesis [26]. Toxicological research has demonstrated that telbivudine has no carcinogenic, teratogenic, or mutagenic effects, and no mitochondrial toxicity [26, 27]. The duration of antiviral treatment should be considered, because it requires several weeks to suppress serum viral loads effectively. It would be desirable to minimize the adverse events to fetal development while to suppress serum HBV DNA levels of pregnant women as early as possible, so that it can probably enhance the efficacy of the antiviral agent in reducing MTCT of HBV. Therefore, we evaluated the patients received antiviral treatment at 12-34 weeks of gestation more earlier than previous studies, and the limited safety data suggest that it did not increase the risks of adverse events of maternal or fetal. The results of our study was similar to two previous studies, which the initiation of NA treatment time were at week $12-30$ and week 8-32, but those studies were only enrolled $\mathrm{HBeAg}$ positive women with chronic hepatitis B $[16,28]$. Moreover, another previous study shown that treatment with telbivudine during the second and third trimesters of pregnancy safely blocked perinatal transmission of HBV and infants born to telbivudine-treated mothers showed normal growth and development during long-term follow-up of up to 5 years [14].

The most common telbivudine-related adverse events was increased serum CK levels [29]. In our study, CK levels was slightly increased in 7 cases from telbivudine group and spontaneously recovered without drug withdrawal. In telbivudine group, fetal malformation was found in two cases ( 1 case at antenatal examination after 4 weeks of treatment, and another newborn had a ruptured abdominal aortic aneurysm in the perinatal period), and it's no statistically significant difference compared with that in control group. These findings indicated that telbivudine treatment is safe in the second and third trimesters. Another study of 489 pregnancies found that treatment with telbivudine presents a favorable safety profile without increasing the rates of live birth defect, spontaneous abortion or elective termination, and neonatal toxicity [30].

There were a few limitations of this study. First, there maybe have a risk of bias in this single center and observational study. Second, all the patients were naïve treatment patients with serum HBV DNA > $6.0 \log _{10} \mathrm{IU} / \mathrm{mL}$, the efficacy of telbivudine in the $\mathrm{CHB}$ patients with a 
history of antiviral therapy on MTCT was still unknown. Third, we didn't detect genotypes of HBV in this study, which was a important point for antiviral treatment. However, viral genotypes have diverse geographical distribution and the genotypes of HBV are almost genotype $\mathrm{B}$ or $\mathrm{C}$ in China according to a previous study [31].

\section{Conclusions}

The antiviral therapy in $\mathrm{HBeAg}$ positive women whose HBV DNA are $>10^{6} \mathrm{IU} / \mathrm{mL}$ was started at the third trimester to prevent MTCT is recommended. However, it's still have failed immunoprophylaxis in some high viral load CHB mothers. Antiviral therapy start at a earlier time may be a solution, but we have insufficient data to prove that it is a safe method. In this study, we found that telbivudine treatment at 12-34 weeks of gestation in $\mathrm{HBeAg}$ positive or negative $\mathrm{CHB}$ mothers with serum HBV DNA $>6.0 \log _{10} \mathrm{IU} / \mathrm{mL}$ is well tolerance and safe in our limited data. Thus, telbivudine can safely reduce mother-to-child transmission in chronic hepatitis B women after 12 weeks of gestation.

\section{Abbreviations}

AASLD: American Association for the Study of Liver Disease; ALT: Alanine aminotransferase; APASL: Asian Pacific Association for the Study of the Liver; AST: Aspartate transaminase; CHB: Chronic hepatitis B; CK: Creatine kinase; EASL: European Association for the Study of the Liver; HBeAg: Hepatitis B e antigen; HBIG: Hepatitis B immune globulin; HBsAg: Hepatitis B surface antigen; HBV: Hepatitis B virus; MTCT: Mother-to-child transmission; TBIL: Total bilirubin; ULN: Upper limit of normal

\section{Acknowledgements}

Not Applicable.

\section{Authors' contributions}

LFH: project development, data collection, and data analysis. JMZ: checked the results, and manuscript writing. $L Q Z, H B G, L X C, Q L X, Y H C, X Z$ and $C P$ : data collection. LFY: study designing and manuscript supervising. All authors read and approved the final manuscript.

\section{Funding}

This work was supported by Fuzhou science and technology plan project (No.2012-S-157-3) of Lv-Feng Yao, Fuzhou clinical key department of infectious diseases (No.201510301) of Li-Fen Han and Shanghai Natural Science Foundation Project (No.19ZR1407800) of Jian-Ming Zheng, China. Lv-Feng Yao designed this study and supervised the manuscript. Li-Fen Han performed this study and play a role in collection, analysis, and interpretation of data. Jian-Ming Zheng checked data and wrote the draft

\section{Availability of data and materials}

Data supporting our findings is contained within the manuscript. Data is available from the corresponding author upon request. Identifying/ confidential patient data however will not be shared.

\section{Ethics approval and consent to participate}

This prospective observational study was approved by the Ethics Committee of Mengchao Hepatobiliary Hospital of Fujian Medical University (award number 2011-001-01). All the CHB mothers signed informed consent, and all subjects consented before screening for the study.

\section{Consent for publication}

Not applicable.

\section{Competing interests}

The authors declare that they have no competing interests.

\section{Author details}

'Department of Liver Diseases, Mengchao Hepatobiliary Hospital of Fujian Medical University, Fuzhou 350025, China. ${ }^{2}$ Department of Infectious Diseases, Huashan Hospital, Fudan University, Shanghai 200040, China. ${ }^{3}$ Department of Liver Diseases, The Second Hospital of Longyan, Fuzhou 350025, China.

Received: 29 March 2018 Accepted: 3 July 2019

Published online: 12 July 2019

\section{References}

1. Liang X, Bi S, Yang W, Wang L, Cui G, Cui F, Zhang Y, Liu J, Gong X, Chen Y, et al. Epidemiological serosurvey of hepatitis B in China--declining HBV prevalence due to hepatitis B vaccination. Vaccine. 2009;27(47):6550-7.

2. Alter MJ, Hadler SC, Margolis HS, Alexander WJ, Hu PY, Judson FN, Mares A, Miller JK, Moyer LA. The changing epidemiology of hepatitis B in the United States. Need for alternative vaccination strategies. JAMA. 1990;263(9):1218-22.

3. Stevens CE, Beasley RP, Tsui J, Lee WC. Vertical transmission of hepatitis B antigen in Taiwan. N Engl J Med. 1975;292(15):771-4.

4. Beasley RP, Hwang LY, Lin CC, Leu ML, Stevens CE, Szmuness W, Chen KP. Incidence of hepatitis $B$ virus infections in preschool children in Taiwan. J Infect Dis. 1982;146(2):198-204.

5. Livingston SE, Simonetti JP, Bulkow LR, Homan CE, Snowball MM, Cagle HH, Negus SE, McMahon BJ. Clearance of hepatitis B e antigen in patients with chronic hepatitis B and genotypes A, B, C, D, and F. Gastroenterology. 2007; 133(5):1452-7.

6. Wiseman E, Fraser MA, Holden S, Glass A, Kidson BL, Heron LG, Maley MW, Ayres A, Locarnini SA, Levy MT. Perinatal transmission of hepatitis B virus: an Australian experience. Med J Aust. 2009;190(9):489-92.

7. Burk RD, Hwang LY, Ho GY, Shafritz DA, Beasley RP. Outcome of perinatal hepatitis B virus exposure is dependent on maternal virus load. J Infect Dis. 1994;170(6):1418-23.

8. Li XM, Shi MF, Yang YB, Shi ZJ, Hou HY, Shen HM, Teng BQ. Effect of hepatitis $B$ immunoglobulin on interruption of HBV intrauterine infection. World J Gastroenterol. 2004:10(21):3215-7.

9. Zou H, Chen Y, Duan Z, Zhang H, Pan C. Virologic factors associated with failure to passive-active immunoprophylaxis in infants born to $\mathrm{HBsAg}$ positive mothers. J Viral Hepat. 2012;9(2):e18-25.

10. Mast EE, Margolis HS, Fiore AE, Brink EW, Goldstein ST, Wang SA, Moyer LA, Bell BP, Alter MJ. (ACIP). ACoIP. A comprehensive immunization strategy to eliminate transmission of hepatitis B virus infection in the United States: recommendations of the advisory committee on immunization practices (ACIP) part 1: immunization of infants, children, and adolescents. MMWR Recomm Rep. 2005;54:RR-16):1-31.

11. Han L, Zhang HW, Xie JX, Zhang Q, Wang HY, Cao GW. A meta-analysis of lamivudine for interruption of mother-to-child transmission of hepatitis $B$ virus. World J Gastroenterol. 2011;17(38):4321-33.

12. Brown RS Jr, McMahon BJ, Lok AS, Wong JB, Ahmed AT, Mouchli MA, Wang Z, Prokop LJ, Murad MH, Mohammed K. Antiviral therapy in chronic hepatitis B viral infection during pregnancy: a systematic review and metaanalysis. Hepatology. 2016;63(1):319-33.

13. Terrault NA, Bzowej NH, Chang KM, Hwang JP, Jonas MM, Murad MH, American Association for the Study of Liver Diseases. AASLD guidelines for treatment of chronic hepatitis B. Hepatology. 2016:63(1):261-83.

14. Han GR, Jiang HX, Wang CM, Ding Y, Wang GJ, Yue X, Zhou L, Zhao W. Long-term safety and efficacy of telbivudine in infants born to mothers treated during the second or third trimesters of pregnancy. J Viral Hepat. 2017;24(6):514-21.

15. Han GR, Cao MK, Zhao W, Jiang HX, Wang CM, Bai SF, Yue X, Wang GJ, Tang $X$, Fang ZX. A prospective and open-label study for the efficacy and safety of telbivudine in pregnancy for the prevention of perinatal transmission of hepatitis B virus infection. J Hepatol. 2011;55(6):1215-21.

16. Yu MM, Jiang Q, Ji Y, Wu KH, Ju LL, Tang X, Yang YF. Comparison of telbivudine versus lamivudine in interrupting perinatal transmission of hepatitis B virus. J Clin Virol. 2014;61(1):55-60.

17. Zhang H, Pan CQ, Pang Q, Tian R, Yan M, Liu X. Telbivudine or lamivudine use in late pregnancy safely reduces perinatal transmission of hepatitis $B$ virus in real-life practice. Hepatology. 2014;60(2):468-76.

18. Chen T, Wang J, Feng Y, Yan Z, Zhang T, Liu M, Bai Y, Song H, Liu H, Yang $Y$, et al. Dynamic changes of HBV markers and HBV DNA load in infants 
born to $\mathrm{HBsAg}(+)$ mothers: can positivity of HBsAg or HBV DNA at birth be an indicator for HBV infection of infants? BMC Infect Dis. 2013;13:524.

19. Sun KX, Li J, Zhu FC, Liu JX, Li RC, Zhai XJ, Li YP, Chang ZJ, Nie JJ, Zhuang $\mathrm{H}$. A predictive value of quantitative HBsAg for serum HBV DNA level among HBeAg-positive pregnant women. Vaccine. 2012;30(36):5335-40.

20. Liu Y, Li G, Chen Y, Wang X, Ruan Y, Zou L, Zhang W. A descriptive analysis of the indications for caesarean section in mainland China. BMC Pregnancy Childbirth. 2014;14:410.

21. Chinese Society of Hepatology and Chinese Society of Infectious Diseases CMA. The guideline of prevention and treatment for chronic hepatitis $B$ (2010 version). Zhonghua Liu Xing Bing Xue Za Zhi. 2011;32(4):405-15.

22. Chinese Society of Hepatology CMACSoID. Chinese Medical Association, Hou $\mathrm{J}$, lai W. [the guideline of prevention and treatment for chronic hepatitis B: a 2015 update]. Zhonghua Gan Zang Bing Za Zhi. 2015;23(12):888-905.

23. European Association For The Study Of The Liver. EASL clinical practice guidelines: management of chronic hepatitis B virus infection. J Hepatol. 2012:57(1):167-85.

24. Sarin SK, Kumar M, Lau GK, Abbas Z, Chan HL, Chen CJ, Chen DS, Chen HL, Chen PJ, Chien RN, et al. Asian-Pacific clinical practice guidelines on the management of hepatitis B: a 2015 update. Hepatol Int. 2016;10(1):1-98.

25. Choi $H$, Wang L, Lin $X$, Spengler JD, Perera FP. Fetal window of vulnerability to airborne polycyclic aromatic hydrocarbons on proportional intrauterine growth restriction. PLoS One. 2012;7(4):e35464.

26. Dienstag J, Easley C, Kirkpatrick P. Telbivudine. Nat Rev Drug Discov. 2007; 6(4):267-8.

27. Amarapurkar DN. Telbivudine: a new treatment for chronic hepatitis B. World J Gastroenterol. 2007;13(46):6150-5

28. Pan CQ, Han GR, Jiang HX, Zhao W, Cao MK, Wang CM, Yue X, Wang GJ. Telbivudine prevents vertical transmission from HBeAg-positive women with chronic hepatitis B. Clin Gastroenterol Hepatol. 2012;10(5):520-6.

29. Wang Y, Thongsawat S, Gane EJ, Liaw YF, Jia J, Hou J, Chan HL, Papatheodoridis G, Wan M, Niu J, et al. Efficacy and safety of continuous 4year telbivudine treatment in patients with chronic hepatitis B. J Viral Hepat. 2013;20(4):e37-46.

30. Piratvisuth T, Han GR, Pol S, Dong Y, Trylesinski A. Comprehensive review of telbivudine in pregnant women with chronic hepatitis B. World J Hepatol. 2016;8(9):452-60.

31. Fan R, Sun J, Yuan Q, Xie Q, Bai X, Ning Q, Cheng J, Yu Y, Niu J, Shi G, et al. Baseline quantitative hepatitis $B$ core antibody titre alone strongly predicts HBeAg seroconversion across chronic hepatitis B patients treated with peginterferon or nucleos(t) ide analogues. Gut. 2016;65(2):313-20.

\section{Publisher's Note}

Springer Nature remains neutral with regard to jurisdictional claims in published maps and institutional affiliations.

Ready to submit your research? Choose BMC and benefit from:

- fast, convenient online submission

- thorough peer review by experienced researchers in your field

- rapid publication on acceptance

- support for research data, including large and complex data types

- gold Open Access which fosters wider collaboration and increased citations

- maximum visibility for your research: over $100 \mathrm{M}$ website views per year

At $\mathrm{BMC}$, research is always in progress.

Learn more biomedcentral.com/submissions 